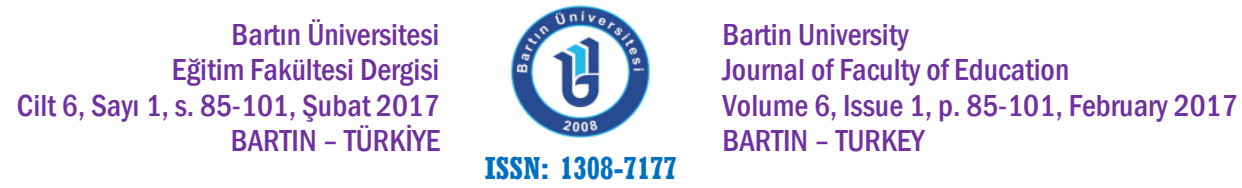

Doi: $10.14686 /$ buefad. 266448

\title{
Üniversitelerde Unvan Ayrımcılığı
}

Sultan Bilge KESKINLILIÇ KARA, Yrd. Doç. Dr. İstanbul Sabahattin Zaim Üniversitesi Eğitim Fakültesi, bilge.kara@izu.edu.tr

Öz: Bu araştırmanın amacı üniversitelerde yaşanan unvan ayrımcılı̆ııı, bu ayrımclığın etkilerini ve akademisyenlerin ayrımcılık karşısında uyguladıkları çözüm yollarını belirlemektir. Araştırma olgu bilim türünde desenlenmiştir. Araştırmanın çalışma grubunu isstanbul'daki üniversitelerde görev yapan ve unvan ayrımcılı̆̆ı olgusunu deneyimleyen 34 öğretim elemanı oluşturmaktadır. Veri toplama aracı olarak araştırmacı tarafından geliştirilmiş olan yarı yapılandırılmış görüşme formu kullanılmıştır. Araştırma sonucuna göre öğretim elemanlarının görev ve unvanlarına göre farklı unvan temelli ayrımcı davranışa maruz kaldıkları görülmüştür. Yrd. Doç. Dr. olarak çalışan öğretim elemanlarının en fazla aşağılama ve adaletsiz ders dağıtılmasına maruz kaldıkları, öğretim görevlilerin en fazla adaletsiz ders dağıtımı ve fazla sınav görevi verilmesine maruz kaldıkları, araştırma görevlilerinin ise görev tanımı dışında işlerin verilmesi, aşağılama, karara katılımın engellenmesi ve fazla sınav görevi verilmesine maruz kaldıkları belirlenmiştir. Unvan temelli ayrımcı davranışların çoğunluklu olarak yöneticiler, Doç. Dr. ve Prof. Dr. ile Yrd. Doç. Dr. tarafından sergilendiği belirlenmiştir. Öğretim elemanlarına göre ayrımcılı̆ı̆n nedeni yüksek ego, daha önce benzer şekilde ayrımcılığa uğramıs olma ve rekabetçilik olarak belirtilmiştir. Ayrımcılığa maruz kalan öğretim elemanlarının kuruma bağılıklarının, iş yapma isteklerinin azaldığı ve mutsuz oldukları da araştırmanın önemli sonuçlarından biridir. Unvan temelli ayrımcı davranışlar karşııında öğretim elemanlarının çoğunluklu olarak iletişim kurmama, sessizlik ve yükselmek için daha çok çalışmak gibi çözüm yollarını benimsedikleri belirlenmiştir.

Anahtar Kelimeler: yükseköğretim, akademisyen, öğretim elemanı, ayrımcılık.

\section{Title Based Discrimination in Universities}

Abstract: The aim of this study is to determine the title based discrimination in universities, effects of it on academicians and the solutions of academicians against discrimination. The study employed a phenomenologic research design. The sample consist of 34 academicians who have experienced title based discrimination. A semi-structured interview form, developed by the author, was used as data collection tool. As a result of the research it was found that academicians are exposed to different title-based discriminatory behaviors according to their duties and titles. It has been determined that academicians who work as assistant professors are mostly exposed to humiliation and unfair distribution of courses; lecturers are exposed to unfair course distribution and over-examination task; research assistants have been given jobs other than job descriptions, humiliation, obstruction of participation in the meetings, and over-examination tasks. It has been determined that title based discrimination behaviors are mostly displayed by managers, associate professors, professors and assistant professors. According to the academicians title based discriminations stems from high ego, being similarly discriminated before and competitive personality. It has been also determined that when academicians exposed to title based discrimination they became unhappy, their organizational commitment level and desire for work reduce. It has been found that academicians against discriminations have adopted solutions such as not communicating, silence and working harder to have higher status.

Key Words: higher education, academician, discrimination. 


\section{GiRiş}

Üniversiteler sorgulamanın, özgür ve eleştirel düşünmenin öğretildiği, bilimsel bilginin üstünlüğünün ortaya konduğu eğitim kurumlarıdır (ilham, 2008). Eğitim kurumları hiyerarşik bir sırada düşünülecek olursa şüphesiz üniversiteler bu hiyerarşide en üst sırada yer alan örgütlerdir. Üniversitelerin bu öneminden hareketle, Türkiye'de son yıllarda yükseköğretime erişimle ilgili önemli adımlar atılmıştır. "Her ile bir üniversite" sloganı ile başlayarak 2006 yılında 15 yeni devlet üniversitesi kurulmuştur. Bunu izleyen zamanlarda da sayıları hızla artan vakıf üniversiteleri ile birlikte şu an Türkiye'de 112 'si devlet, 65'i vakıf ve 6 'sı vakıf meslek yüksekokulu olmak üzere toplam 183 yükseköğretim kurumu bulunmaktadır. Buna bağlı olarak benzer oranda bir artış, akademisyen ve öğrenci sayılarında da yaşanmış, 2005 yılında 2.999.421 olan toplam öğrenci sayısı, 2016 yılında 6.689.185'e, 79.555 olan akademisyen sayısı 2016 yılında 146.124'e yükselmiştir (YÖK, 2016). Yükseköğretimde niceliğin bu hızla artışıyla beraber öğretim elemanı ve alt yapı gereksinimlerinin karşılanamamasından kaynaklı olarak üniversitelerden beklenen eğitim, öğretim, araştırma ve toplumsal hizmet kalitesinin düştüğü, kurumsallaşamama ve dolayısıyla nitelikte ciddi bir zedelenmeye neden olduğu (Doğan, 2013; Karakütük ve Özdemir, 2011) yönünde eleştiriler yapılmaktadır. Bunun yanında bu artışı, bölgesel kalkınmayı hızlandırması ve ekonomik katkılarından dolayı olumlu bulan (Arap, 2010) araştırmacılar da mevcuttur. Yükseköğretimdeki hızlı büyüme ile birlikte sorunların artması ve farklılaşması doğaldır. Önemli olan bu sorunları fark edip zamanında çözüm üretebilmektir. Üniversitelerin sorunlarının yanında bu üniversitelerde görev yapan akademisyenlerin de çeşitli sorunları söz konusudur. Akademisyenlerin sorunları arasında ücret düşüklüğü, yükselme zorlukları, atamalardaki haksızlıklar, ayrımcılık, olumsuz kişiler arası ilişkiler, saygınlık kaybı, ders yüklerinin fazla olması, bilimsel çalışmalar için destek eksikliği, alanla ilgili yayınları takip edememe sıralanabilir (Mengi ve SchregImann, 2013; Arı, 2007; Artut, 2008; TÜSIAD, 2008). Bu sorunlar aynı zamanda araştırmacıların üretkenliğini etkileyebilecek niteliktedir (Mengi ve SchregImann, 2013). Bireysel ve kurumsal etkilerinin yanında akademisyenlerin davranışları ve bu davranışların her bir alt boyutu toplumsal açıdan da önemli etki gücüne sahiptir. Bu doğrultuda üniversitelerde yaşanan unvan temelli ayrımcılık araştırmanın çalışma konusu olarak belirlenmiştir.

Unvan ayrımcılığı bir kişiye unvanı nedeniyle gösterilen farklı tavır, önyargı ve davranışlardır. Unvan ayrımcılığııın, özellikle çalışanların herhangi bir unvana sahip olduğu, yükselme ve sınav yoluyla daha farklı unvanlar alabildikleri üniversite gibi örgütlerde yaşanma olasılığı yüksektir. Unvan ayrımcılığının temel dayanağı, bir unvanı diğer bir unvana üstün tutarak örgüt içindeki haklardan daha fazla ve kolay yararlanmayı ummaktır. Unvan ayrımcılı̆̆ı kısaca karşıdaki kişinin sahip olduğu unvan nedeniyle adil olmayan davranışlar sergileme olarak da tanımlanabilir.

İ̧̧yerinde ayrımcılı̆̆ın önüne geçmek için ILO tarafından 111 sayılı "İş ve Meslekte Ayrımcılığa Karşı Korumaya îlişkin Sözleşme" yürürlüğe konmuştur. Sözleşmenin birinci maddesinin birinci fıkrasında ayrımcılık kavramı "ırk, renk, cinsiyet, din, siyasal inanç, ulusal veya sosyal menşe bakımından yapılan iş veya meslek edinmede veya edinilen iş veya meslekte tabi olunacak muamelede eşitliği yok edici veya bozucu etkisi olan her türlü ayrılık gözetme, ayrı tutma veya üstün tutma" olarak ifade edilmiştir. Bu maddede işyerinde ayrımcılık kaynağı olarak unvan belirtilmemiş olsa bile "muamelede eşitliği yok edici veya bozucu etkisi olan her türlü ayrılık gözetme, ayrı tutma" ifadesi unvana dayalı ayrımcılığı da içermektedir.

Ayrımcı davranışlar, bağlılık, iş tatmini, örgütsel vatandaşlık, güven ve motivasyon gibi pozitif çıktılardan ziyade tükenmişlik, iş stresi, işten ayrılma niyeti, sinizm gibi negatif çıktılara neden olabilir. Ayrımcılık, dışlama, adaletsizlik ve etik olmayan davranışların üniversitelerde 
yaşanması sadece orada görev yapan ya da öğrenim gören öğrencileri değil aynı zamanda toplumun üniversitelere olan güvenini etkileyerek üniversitelerin itibarını da olumsuz yönde etkileyebilir. Bu tür durumların kurumsal itibarı zedelediğine yönelik (Saylı ve Yaşar-Uğurlu, 2007) alanyazın çalışmaları mevcuttur. Her tür ayrımcılık hem etik dışı örgütsel davranıştır (Gül, 2006) hem de centilmenlik ve nezaket ile örtüşmemektedir. Bu tür davranışlar çalışanların tutum ve davranışlarının oluşturduğu örgütsel iklimi de olumsuz yönde etkileme gücüne sahiptir.

Akademisyenlerin temel etkinlikleri, öğretme, araştırma, yönetim ve toplum hizmetidir (Marsh ve Hattie, 2002). Onların mutsuz olmaları bu temel etkinliklerinin niteliğini etkileyen önemli değişkenlerden biridir (Eroğlu, 2004). Yükseköğretimde kaliteyi artırmanın koşullarından biri akademisyenlerin çalışma ortamının sağlıklı olmasıdır (Korkut, 2001). Ancak ayrımcılık gibi olumsuz örgüt içi davranışların sergilendiği ortamlarda çalışanların mutluluğundan ve verimli çalışmalarından söz etmek zordur.

Türkiye'deki araştırmalar incelendiğinde akademisyenler ile ilgili yapılmış çalışmaların odak noktasını yıldırma (Celep ve Konaklı, 2013; Mete, 2013; Ayan ve Şahbudak, 2012), tükenmişlik (Naktiyok ve Karabey, 2005; Çavuş, Gök ve Kurtay, 2007), bağlılık (Aydemir ve Erşan, 2011; Çöl ve Gül, 2005), iş doyumu (Bilge, Akman ve Kelecioğlu, 2007), iş memnuniyeti (Paksoy, 2007), sessizlik (Yaman ve Ruçlar, 2014) gibi konular oluşturmaktadır. Bunların yanında akademisyenlerin sorunlarını konu alan araştırmalar da (Yeşil ve Fidan, 2015; Gündüz, 2013; Ergöl, Koç, Eroğlu ve Taşkın, 2012; Şentürk, 2012; Yılmaz ve Özdemir, 2012; Artut, 2008; Arı, 2007; Korkut, Mustan ve Yalçınkaya, 1999) olmakla birlikte doğrudan akademisyenlerin maruz kaldığı unvan ayrımcılığına yönelik bir araştırma olmadığı görülmektedir. Bu nedenle bu araştırmanın amacı üniversitelerde yaşanan unvan ayrımcılığını, bu ayrımcılığın etkilerini ve akademisyenlerin ayrımcılık karşısındaki çözüm yollarını belirlemektir. Çalışma sonuçlarının akademisyenlerin yaşadığı ayrımcılık sorununa dikkat çekerek bu konuda alınacak kararlara ve politikalara veri desteği sağlayacağı düşünülmektedir.

\section{YÖNTEM}

Bu çalışma bir olgu bilim araştırmasıdır. Olgu bilim araştırmalarında farkında olduğumuz ancak derinlemesine bir bilgiye sahip olmadığımız olgulara odaklanılmakta ve bu olgu üzerinde çalışılmaktadır (Yıldırım ve şimşek, 2008). Bu araştırmada üzerinde çalışılan olgu, unvan ayrımcılı̆ıdır ve unvan ayrımcılığına ilişkin derinlemesine veriler sunmak amaçlanmıştır.

\section{1. Çalışma Grubu}

Olgu bilim araştırmalarında çalışma grubu, araştırmada üzerinde çalışılan olguyu deneyimleyen ve bu olguyu yansıtabilecek bireylerden oluşmalıdır (Richards ve Morse, 2012). Bu araştırmanın çalışma grubunu isstanbul'daki üniversitelerde görev yapan ve unvan ayrımcılığı olgusunu deneyimleyen 34 öğretim elemanı oluşturmaktadır. Çalışma grubu amaçlı örneklem yöntemlerinden ölçüt örnekleme tekniği ile belirlenmiştir. Bu çalışmada ölçüt, öğretim elemanlarının üniversitede çalıştığı süre içinde unvan ayrımcılığına uğradığı algısıdır. Çalışma grubundaki öğretim elemanlarının 14'ü Yrd. Doç. Dr., 13'ü öğretim görevlisi, 7'si ise araştırma görevlisi olarak çalışmaktadır. Çalışma grubundaki öğretim elemanlarının 12'si kadın, 22'si erkektir, yaşları 29 ve 61 arasında değişmektedir. Öğretim elemanlarının 9'u Eğitim Fakültesinde, 5’i Fen Edebiyat Fakültesinde, 4'ü íktisat Fakültesinde, 4'ü Yabancı Diller Yüksek Okulunda, 4'ü Siyasal Bilgiler Fakültesinde, 3'ü İşletme Fakültesinde, 2'si Mimarlık Fakültesinde, 1'i Hukuk Fakültesinde, 1'i Sağlık Bilimleri Fakültesinde, 1'i Mühendislik 
Fakültesinde görev yapmaktadır. Çalışma grubunun tamamı devlet üniversitelerinde görev yapmaktadır. Araştırma planlanırken vakıf üniversiteleri de araştırmaya dahil edilmiş ancak veri toplama sürecinde öğretim elemanlarının bazı soruları yanıtlamak istememesi, bazı sorulara ayrıntılı yanıtlar vermemesi ve araştırmada incelenen olgunun tedirginlik yaratması üzerine katılımcıları da zorlamamak adına bu üniversitelerde veri toplama gerçekleştirilmemiştir.

\subsection{Veri Toplama Aracı}

Veri toplama aracı olarak araştırmacı tarafından geliştirilmiş olan yarı yapılandırılmış görüşme formu kullanılmıştır. Görüşme formundaki sorular, unvan temelli ayrımcı davranışların neler olduğunu, unvan ayrımcılığına maruz kalınan dönemleri, ayrımcı davranışı kimlerin sergilediği, ayrımcılığın bireysel ve örgütsel etkilerinin neler olduğunu, unvan ayrımcılığının nedenlerini ve unvan ayrımcılığı karşısında uygulanan çözüm yollarını belirlemeye yönelik olarak hazırlanmıştır. Görüşme formunda, 2 alan uzmanı ve 1 dilbilimcinin de görüşleri alınarak gerekli düzeltmeler yapılmıştır. Görüşme sorularının anlaşıır olup olmadığını belirlemek için bir öğretim elemanı ile ön görüşme yapıldıktan sonra görüşme formuna son şekli verilmiştir. Görüşmeler 2016 yılı Mart-Haziran ayları arasında araştırmacı tarafından gerçekleştirilmiştir. Görüşmelerde 17 öğretim elemanı ses kaydına izin vermiş ve bu görüşmeler ses kaydından sonra kağıda aktarıımıştır. Ses kaydı yapılmasına izin vermeyen öğretim elemanları ile yapılan görüşmeler görüşme esnasında doğrudan kağıda yazıımıştır.

\subsection{Verilerin Analizi}

Verilerin analizinde tematik analiz tekniği kullanılmıştır. Görüşmeler ile elde edilen verilerin analizinde güvenirliği sağlamak adına bir alan uzmanı akademisyen ile birlikte, görüş birliğine varılarak, kodlar ve temalar oluşturulmuştur. Kodlama sürecinde veriler dikkatli bir şekilde okunmuş, araştırmanın amacı doğrultusunda önemli kodlar belirlenmiştir. Oluşturulan kod listesinin ardından birbiriyle ilişkili olabilecek olan kodlar bir araya getirilerek temalar oluşturulmuştur. Katılımcı öğretim elemanlarının maruz kaldıkları ayrımcı davranışlar unvana ve göreve göre farklılık gösterdiği belirlendiği için Yrd. Doç. Dr., Araştırma Görevlisi ve Öğretim Görevlileri için ayrı ayrı analiz edilerek tablolaştırılmıştır.

\section{BULGULAR VE YORUM}

Maruz kalınan ayrımcı davranışların niteliği görev ve unvana göre farklıık gösterdiği için analizler ayrı ayrı yapılmıştır. Yapılan analizler sonucunda Yrd. Doç. Dr. olarak görev yapan öğretim elemanlarının maruz kaldıkları unvan temelli ayrımcı davranışlar aşağıdaki şekilde tablolaştırılmıştır:

Tablo 1. Yrd. Doç. Dr. olarak görev yapan öğretim elemanlarının maruz kaldıkları unvan temelli ayrımcı davranışlar

\begin{tabular}{llc}
\hline Temalar & Kodlar & $\mathbf{f}$ \\
\hline \multirow{2}{*}{ Kişiliğe yönelik } & Aşağılama & 5 \\
& Kendini ifade etmenin engellenmesi & 4 \\
\hline & Ders dağılımlarında adaletsizlik & 5
\end{tabular}


Göreve yönelik

Formasyon dersi vermeme

Fazla sınav gözetmenliği verilmesi

Görev tanımı dışında işlerin verilmesi

Kadro vermeme ile şantaj etme

Yrd. Doç. Dr. 'lerin belirttikleri ayrımcı davranışların ilk sırasında aşağılama bulunmaktadır.

Çoğu zaman dekan yardımcı doçent olmamızı ayıp bir şeymiş gibi yüzümüze vurarak 'Siz daha yardımc doçentsiniz, daha çok çalışmanız gerekir yeterli olabilmeniz için' gibi ifadelerle aşağılardı (Yrd. Doç. Dr., 36, Kadın).

Unvandan kaynaklı ayrımcı davranışlarla çok karşılaştım. Bir keresinde bir profesör hocamız şunları söyledi: "Bu yardımcı doçentler ancak yan gelip yatmış. Ne dil çalışmış, ne akademik çalışma yapmış. Senelerce derse girip çıkmışlar, günlük yaşamışlar, yarına hiç bakmamışlar. Elli yaşına gelmiş teyzeden amcadan hayır mı gelir? Bak sen gençsin diye söylüyorum sakın ha üstüne alınma, sen de 50 yaşına gelince hala yardımcı doçent kalma. Zaten herkes yardıma doçent, ne kolay yardıma doçent olunuyor ya. Elini sallasan eğitimde yardımcı doçent. Hepsi mezara yardımcı doçent olarak girecek” (Yrd. Doç. Dr., 33, Erkek).

Yrd. Doç. Dr.'lerin ders dağılımlarında adaletsizliğe uğradıklarını belirtmeleri araştırmanın bir diğer bulgusudur. Bu adaletsizlik, fazla ders yükü vermek şeklinde olabildiği gibi, daha az ders vererek ek ders almanın engellenmesi şeklinde de olabilmektedir. Bazı durumlarda ders çeşitliliğinin çok fazla olması şeklinde de olabildiği öğretim elemanları tarafından belirtilmiştir.

"Lisans ve yüksek lisans programlarında öncelikli olarak Profesör ve Doçentler istedikleri dersleri alırlar kalan dersleri Yardımcı Doçentler alırdı. Aynı durum tez danışmanlıkları için de geçerli. Kimsenin istemediği, dersle ilgisi olmayan öğrenciler bize verilirdi." (Yardımcı Doçent, 37, Kadın)

Yrd. Doç. Dr.'lerin maruz kaldıkları bir diğer ayrımcı davranış ise kendini ifade etmenin engellenmesidir. Bu engelleme çatışma durumlarında unvanı yüksek olana hak verilip, yardımcı doçentlerin yeterince dinlenmemesi, önemli kararlar alınacağı zaman danışılmaması ve toplantılara çağırılmama şeklinde olduğu belirtilmektedir.

"Sanki Yardımcı Doçentler bir şey bilmez gibi davranıp mesajlar veriyorlar. Anlaşmazlık durumunda onlar haklı oluyor ve her zaman son noktayı onlar koyuyor. Sana söz hakkı vermeye bile tenezzül etmiyorlar." (Yardımcı Doçent, 50, Erkek)

Öğretim görevlilerinin maruz kaldıkları unvan temelli ayrımcı davranışlar aşağıdaki şekilde tablolaştırılmıştır:

Tablo 2: Öğretim görevlilerinin maruz kaldıkları unvan temelli ayrımcı davranışlar

\begin{tabular}{lll}
\hline Temalar & Kodlar & f
\end{tabular}




\begin{tabular}{llc}
\hline & Aşağılama & 4 \\
Kişiliğe yönelik & Muhatap olmama & 2 \\
\hline Göreve yönelik & Ders dağılımlarında adaletsizlik & 7 \\
& Fazla sınav gözetmenliği verilmesi & 6 \\
& Formasyon dersi vermeme & 2 \\
& İhtiyaçların önemsenmemesi & 2 \\
Akademik ilerlemenin engellenmesi & 2 \\
Kurum olanaklarından eşit yararlandırılmama & 2 \\
Yönetim görevine aday olamama & 1 \\
Toplantılara çağırılmama & 1
\end{tabular}

Tablo 2 incelendiğinde öğretim görevlilerinin maruz kaldığı unvan temelli ayrımcı davranışların ilk sırasında ders dağılımlarındaki adaletsizlik gelmektedir. Öğretim görevlileri bu adaletsizlikleri belirtirken kendilerinin fazla bir söz haklarının olmadığını, unvanı daha yüksek olan öğretim üyelerinin istedikleri dersleri önceden aldığını, istenmeyen ve kalan derslerin kendilerine verildiğini belirtmişlerdir. Aynı zamanda ana yerleşke dışındaki veya ilçelerdeki derslerin çoğunlukla öğretim görevlilerine verildiği, öğretim üyelerinin ise ulaşımı daha kolay yerlerdeki dersleri aldıkları da ayrımcı davranışlar arasında belirtilmiştir.

"Eğer öğretim görevlisi iseniz istenmeyen tüm dersler size verilir. Bir alanda çok iyi olsanız bile o dersi isteyen başka bir öğretim üyesi alabilir. Yetmezmiş gibi, ilçelerdeki kampüslerdeki derslere de öğretim görevlilerini gönderirler. Ben hamile olduğum dönemde bile haftanın bir günü 60 km uzaklıktaki ilçedeki derse gittim." (Öğretim Görevlisi, 34, Kadın)

Öğretim görevlilerinin belirttiği bir diğer ayrımcı davranış sınav görevi dağılımlarındaki adaletsizliktir. Öğretim görevlileri, sınav gözetmenliklerinin öğretim görevlilerinin temel görevi gibi görüldüğünü belirtmişlerdir.

"Öğretim üyeleri ek ders alabilecekleri, para getirecek konularda kimseye bir şey düşürmezken sınav gözetmenlikleri asistanlara ve öğretim görevlilerine verilir. Öğretim üyeleri çoğunlukla sınav gözetmenliği yapmazlar." (Öğretim Görevlisi, 51, Erkek)

Öğretim görevlilerin maruz kaldığı bir diğer önemli ayrımcı davranış ise aşağılanmadır. Bunların yanında muhatap olunmaması, formasyon dersi verilmemesi, ihtiyaçların önemsenmemesi ve akademik ilerlemenin engellenmesi de ayrımcı davranışlar arasında belirtilmiştir.

"Öğretim görevlileri fakültede önemsiz eleman olarak niteleniyorlar. Tepeden bakma durumuna maruz kalıyorum. Doçent ve yardımcı doçentler onlardan sonra gelirmişiz havasını normal sohbet ortamlarında bile sezdirirler." (Öğretim Görevlisi, 39, Erkek) 
Tablo 3: Araştırma Görevlilerin maruz kaldıkları unvan temelli ayrımcı davranışlar

\begin{tabular}{lll}
\hline Temalar & Kodlar & F \\
\hline \multirow{2}{*}{ Kişiliğe yönelik } & Aşağılama & 3 \\
& Muhatap olmama & 3 \\
& Özel yaşama ve alana saygısızlık & 2 \\
\hline \multirow{2}{*}{ Göreve yönelik } & Görev tanımı dışında işler yaptırma & 7 \\
& Fazla sınav gözetmenliği verilmesi & 3 \\
& Karara katılmanın engellenmesi & 3 \\
& Kurum olanaklarından eşit yararlandırılmama & 2 \\
\hline
\end{tabular}

Araştırma görevlilerinin maruz kaldığı unvan temelli ayrımcı davranışlar arasında ilk sırayı görev tanımı dışında işlerin verilmesi almaktadır. Görev tanımı dışında işler çeşitlilik göstermekte ve bölümün sekreterlik işlerinin yaptırılması, açık uçlu sınav kağıtlarının okunmasının istenmesi, öğretim üyesi yerine derse girdirilme, hocanın misafirini otogardan alma, arabasını yıkatma, faturaları ödeme hatta falcı bulma şeklinde bile olabilmektedir.

"Burada her şey unvana bakıyor. Ne yaptığını, nasıl yaptığını, ne zaman yaptığını unvanın belirliyor. Yaşımız kaç olursa olsun, hocaların kendi işlerini yapıyoruz. Kadro alamama korkusu ile yapıyoruz. Yeri geliyor arabasını bile yıkatıyoruz. Her zaman olmuyor ama olduğu da oluyor." (Araştırma Görevlisi, 27, Erkek)

"Bu ayrımcılığı çok yaşadım. Açık uçlu sınav kağıtlarının okunmasının istenmesi (yaklaşık 400 öğrenci her öğrenci 8 sayfa yazdığı)- hafta sonu formasyon derslerine 1 dönem girilmesinin istenmesi (kendisi de zamanında hocalarının hafta sonu derslerine girmiş eee sıra bizde)-uzaktan eğitim derslerini kamerayı açmadan (ki araştırma görevlisinin yaptığı ortaya çıkmasın) yapılmasının istenmesi-ödevlerin okunması- gibi etik dışı davranışların çok da normalmiş gibi yapılmasının istenmesi." (Araştırma Görevlisi, 33, Kadın).

Araştırma görevlilerinin maruz kaldığı, kişiliğe yönelik olarak yapılan ayrımcı davranışların aşağılama ve muhatap almama olduğu belirlenmiştir.

"Unvan olarak benden daha yüksek mertebede bulunan hocalar tarafından küçümseyici ve aşağılayıcı konuşmalara ve hitaplara maruz kaldım. Unvan olarak daha yüksek olan öğretim elemanların birbirlerinden kişisel işlerini yapmalarını istemezken benden istediler. Dekan karşısına geçtiğimizde, hocalar göz göre göre kendi hatalarını benim üstüme attılar. Hataları anlaşıldığında da özür dilemediler. 'o senin hocan, olur böyle şeyler' gibi ifadelerle karşıllaştım ve içimde sindirmek zorunda kaldım." ( Araştırma Görevlisi, 26, Kadın, 26)

"Kongre ve konferanslarda bile ayrımcılık fazlasıyla hissediliyor. Unvan olarak yüksek olan hocalar genellikle birbirleriyle muhatap olmayı tercih ediyorlar. Protokol anlayışı ön plana çıkıyor." (Araştırma Görevlisi, 30, Kadın) 
Göreve yönelik olarak yapılan ayrımcı davranışların ise fazla sınav gözetmenliği verilmesi ve karara katılmanın engellenmesi olduğu belirtilmiştir. Araştırma görevlilerinin yanıtlarına göre karara katılmanın engellenmesi, çoğunlukla toplantılara çağrılmama şeklinde olmaktadır.

"Fazlasıyla yaşadım ve yaşamaktayım. En basit örneği, rektörlük tarafından yapılacak toplantılara araştırma görevlileri haricindeki tüm çalışanların çağırılması." (Araştırma Görevlisi, 27, Erkek)

Bir araştırma görevlisinin yanıtları arasında belirttiği olay dikkat çekicidir. Öğretim üyelerinin araştırma görevlilerinin özel alanlarına müdahale etmesini aşağıdaki şekilde ifade etmiştir:

"Doğum günü vb. etkinlikler sorulmadan, izin ve onay alınmadan araştırma görevlilerinin odalarında yapılıyor. Bulaşıklar ve çöpler bize bırakılıyor. Hocalar birbirlerinin eşyalarını izin alarak kullanırken bizim odamızdaki ve masamızdaki eşyalar izin almadan kullanılıyor." (Araştırma Görevlisi, 30, Kadın)

Unvan ayrımcılığının en fazla yaşandığı zamana ilişkin tablo ve açıklamaları aşağıda verilmiştir.

Tablo 4: Unvan ayrımcılığının en fazla yaşandığı dönemler

\begin{tabular}{ll}
\hline Zaman & F \\
\hline Belli bir dönemi veya zamanı yok & 23 \\
Ders dağılım ve programı dönemlerinde & 8 \\
Sınav görevlerinin verildiği zamanlarda & 5 \\
İ̧lerin yoğun olduğu zamanlarda & 4 \\
Görev uzatma dönemlerinde & 2 \\
Toplantı zamanlarında & 1
\end{tabular}

Tablo 4'e göre öğretim elemanları, ayrımcılığa maruz kaldıkları belli bir zamanın olmadığını, herhangi bir zamanda bunun yaşandığını belirtmişlerdir.

"Bunun zamanla bir ilgisi olmuyor genelde. Her an başıma gelebiliyor."(Araştırma Görevlisi, 27, Erkek)

Belirli zamanlarda yoğunlukta olduğunu düşünen öğretim elemanları ise bunun yoğunluklu olarak ders ve sınav görevlerinin planlandığı dönemlerde yaşandığını belirtmişlerdir. Bu yanıt aynı zamanda öğretim elemanlarının ayrımcı davranış olarak belirttikleri ders ve sınav görevi dağılımlarındaki adaletsizlik ile de paralellik göstermektedir

"Çoğunlukla gözetmenlik görevlerini dağıtırken oluyor. Kendilerine daha az biz öğretim görevlilerine daha fazla vermek için." (Öğretim Görevlisi, 61, Erkek) 
Tablo 5: Maruz kalınan ayrımcı davranışların kimler tarafından sergilendiği

\begin{tabular}{ll}
\hline Ayrımcı davranışı sergileyenler & F \\
\hline Yönetim görevinde olanlar & 21 \\
Prof. Dr. ve Doç. Dr'ler & 16 \\
Yrd. Doç. Dr'ler & 13 \\
Memurlar & 3 \\
Öğrenciler & 3 \\
\hline
\end{tabular}

Tablo 5'e göre öğretim elemanları unvan ayrımcılı̆̆ını en fazla sergileyenlerin yönetim görevinde olanlar olduğunu belirtmişlerdir. Bunu sırasıyla Prof. Dr. ve Doç. Dr. ile Yrd. Doç. Dr.'ler izlemektedir. Bu durumda dekanlık ve bölüm başkanlığı gibi yönetim görevinde olanların da akademik unvanlarının çoğunlukla Prof. Dr. ve Doç. Dr. olduğu düşünülürse öğretim üyelerinin akademik unvanları arttıkça sergiledikleri ayrımcı davranışlar da artmaktadır denebilir.

"Unvanı yükseldikçe, ayrımcı davranış belirginleşiyor ve sıklaşıyor. Örneğin, dekan ve rektör tarafından aşağılandığım kadar, hayatta kimse tarafından aşağılanmadım. Ancak, aynı rektör ve aynı dekan unvanı daha yüksek bir hocaya oldukça saygılı davranıyor. Hem de gözümün önünde. Elini sıkıyor, halini hatırını soruyor, sohbet ediyor. Benimle mecbur kalmadıkça muhatap olmuyor ve sözlü iletişimini sadece emir vermekle sınırlı tutuyor." (Araştırma Görevlisi, 30, Kadın)

"Bir üst unvana sahip öğretim elemanından en üst yöneticiye kadar herkes uyguluyor." (Öğretim Görevlisi, 59, Erkek)

Bunların yanında öğretim elemanlarının verdikleri yanıtlar arasında memur ve öğrencilerin de unvan ayrımcılığı yaptığını belirten yanıtlar vardır.

"En fazla Doçent ve Profesörler yapıyor ama memur ve öğrencileri eklemek lazım. Mesela memurlar bizim işleri daha yavaş yapıyor ya da savsaklıyorlar." (Öğretim görevlisi, 46, Erkek)

Tablo 6: Unvan ayrımcılığının nedenleri

\begin{tabular}{lll}
\hline Temalar & Kodlar & $\mathbf{f}$ \\
\hline & Yüksek ego & 9 \\
Uygulayanların bireysel özellikleri & Rekabetçi kişilik & 8 \\
& Unvanı taşıyamamak & 5 \\
& Yetersizlik algısı & 5 \\
\hline
\end{tabular}


davranışa maruz kalmak

Uygulayanların deneyimleri Kültürel yatkınlık

Öğretim elemanlarının verdikleri yanıtlara göre unvan ayrımcılığının nedenleri incelendiğinde uygulayanların bireysel özellikleri ve deneyimleri olmak üzere iki nedenin olduğu belirlenmiştir. Öğretim elemanları en önemli neden olarak, uygulayanların bireysel özelliklerinden olan yüksek ego ve rekabetçi kişilik ve daha önce ayrımcılığı yapan kişinin de aynı davranışa maruz kalması olarak belirtmişlerdir. Bunların yanında sahip olduğu unvanı taşıyamamak ve yetersizlik algısı da nedenler arasında belirtilmiştir.

"Insanlar, astları olarak gördükleri kişileri aşağılayarak kendilerini daha güçlü hissetmek istiyorlar. Bunun bence tek nedeni ayrımcılık yapanın özyeterliğinin düşük olması." (Yrd. Doç. Dr. 35, Kadın)

"Yetersiz öğretim elemanlarının unvanları yükseldikçe kişilik gelişimleri azalmakta. Kendileri kadar bilgili olanların alt kademede olduklarını görünce durumu kabullenmeme." (Öğretim Görevlisi, 59, Erkek)

"Alt kademeler çok ezildikçe, bu ezilenler bir üst kademeye çıkınca kendi ezilmelerinin intikamını geride kalanlardan alıyorlar." (Öğretim Görevlisi, 45, Erkek)

"Bana ayrımcı davranışlarda bulunan insanlar aşağılık kompleksi olan insanlar. Aynı zamanda üniversite dışında bir kişisel değerleri yok. Tutundukları tek şey unvanları ve o unvan olmadan kendilerini değersiz hissediyorlar. Bunu içten içe hissettikleri için, unvanlarını kullanarak kendilerini toplumda daha ayrıcalıklı bir konuma koyarak bu durumla baş ediyorlar. Restoranda rezervasyon yaptırırken dahi prof... Ahmet Mehmet diye yaptırıyorlar. Garsona bile bunu belli etmek istiyorlar." (Araştırma Görevlisi, 30, Kadın)

Tablo 7: Unvan ayrımcılığının etkileri

\begin{tabular}{llc}
\hline Temalar & Kodlar & F \\
\hline Örgütsel etkiler & Kurum bağlılığının azalması & 11 \\
& İş yapma isteğinin azalması & 9 \\
& Performans düşüklüğü & 5 \\
& Düşük iş doyumu & 4 \\
Kuruma karşı öfke & 2 \\
Motivasyon artışı & 2 \\
\hline Mutsuzluk & 10
\end{tabular}

Bireysel etkiler

Gelecek kaygısı

8

Stres

6 
Öğretim elemanlarının verdikleri yanıtlara göre unvan ayrımcılığının örgütsel ve bireysel etkilerinin olduğu belirlenmiştir. Unvan ayrımcılı̆ının en yoğun örgütsel etkisinin kurum bağlılığının azalması olduğu ortaya çıkmıştır.

"Aidiyet duygusunu onurla ve gururla yaşamak istiyoruz ancak ayrımcılık buna engel oluyor ve kendimi bu kuruma ait göremiyorum." (Öğretim Görevlisi, 61, Erkek)

Unvan ayrımcılığının belirlenen en yoğun ikinci örgütsel etkisi ise iş yapma isteğinin azalması olarak belirlenmiştir. Bunun yanında performans ve iş doyumunun düşmesi ve kuruma karşı öfke de etkiler arasında belirtilmiştir.

"İ̧ yapma isteğimi zayıflattı. Akademik çalışma yapmak için isteğim olmadı. İçten içe dekana öfke duymaya başladım. Sürekli olarak arkadaşlarla bir araya gelip bu konu ile ilgili konuşuyorduk. Başka üniversitelere geçmek için başvurularım oldu ve kurumdan ayrıldım." (Yrd. Doç. Dr., 36, Kadın)

Ayrımcılığın belirlenen olumsuz örgütsel etkilerinin yanında motivasyon artışı olarak olumlu bir etki de belirlenmiştir. Ancak burada dikkate alınması gereken nokta örgütsel olarak olumlu değerlendirilen motivasyon artışının bireysel boyutta etkisinin ne olduğunun tam olarak belirgin olmamasıdır. Çünkü örgütler ve bireylerin verimliliğinin ve isteyerek iş yapmalarının kaynağı olan motivasyon gibi olumlu bir sürecin ayrımcılık gibi olumsuz bir davranış karşısında sergilenmesi uzun süreli olmayacak ve hırstan kaynaklı bu durumun bireyin psikolojik iyi oluşuna olumsuz etkileri olabilecektir.

"Beni bu davranışlar olumlu etkiledi ve daha çok çalıştım. Beni hırslandırdı diyebilirim. Ayrımcılık yapıp aşağıladıkları kişinin onlardan akademik olarak daha iyi olduğunu onlara göstermek istedim." (Öğretim Görevlisi,38, Erkek)

Öğretim elemanları, unvan ayrımcılığının bireysel etkileri arasında ilk sırada mutsuzluğu belirtmişlerdir. Bunun yanında gelecek kaygısı, iş stresi ve düşük benlik algısı da belirtilen etkiler arasındadır.

“Bu oldukça üzücü bir durum. Mutsuzluğa engel olamıyorsunuz." (Yrd. Doç. Dr., 34, Erkek)

"Okula gelince, aceba bugün neler yapacaklar diye düşünmek gerginliğe neden oluyor. Sürekli bir stres yaratıyor. Psikolojiden ne kadar anlarsam anlayım gerekli telkini kendime yapamıyorum." (Yrd. Doç. Dr., 46, Erkek)

“Öğrenciler ve üniversite için bir şeyler yapma isteğim zamanla eriyor. Bu bende gelecek kaygısı oluşturuyor. Akademik kamplaşmanın ülke düzeyinde yaşanmaya başlaması üzücü ve bu şekilde bir sınıf bilinci oluşmaz. Araştırma görevlilerinde bunu kaygı ve korkuya neden olarak yapamazsınız." (Araştırma Görevlisi, 30, Erkek)

Tablo 8: Unvan ayrımcılığı karşısında öğretim elemanlarının verdiği tepkiler

\begin{tabular}{llc}
\hline Temalar & Kodlar & F \\
& & \\
\hline Yıldırma & iletissim kurmamak & 11
\end{tabular}


Yapanları görmezden gelmek

6

\begin{tabular}{llc}
\hline Sessizlik & Susmak & 8 \\
\hline & Üst yönetim ile paylaşmak & 3 \\
Muhalefet & İş arkadaşları ile paylaşmak & 3 \\
& Yapanlar ile konuşmak & 1 \\
\hline
\end{tabular}

Duygusal Tepki

Hırslanmak

Öğretim elemanlarının unvan ayrımcılığı karşısında yıldırma, sessizlik, muhalefet davranışları ve duygusal tepkiler sergilediği belirlenmiştir. Yıldırma temasında, unvan ayrımcılığını uygulayan kişilerle iletişimde bulunmama en fazla verilen tepki olarak belirlenmiştir. Bunların yanında ayrımcılık karşısında sessiz kalarak susmak da verilen tepkiler arasındadır. Unvan ayrımcılığı gibi istenmeyen bir durum karşısında öğretim üyelerinin, bu durumun önüne geçmek için, demokratik bir şekilde ifade etmeleri yani açık muhalefet davranışı sergilemeleri beklenir. Ancak verilen yanıtlar öğretim elemanlarının açık muhalefet davranışından ziyade örtük muhalefet ve bilgi uçurmaya başvurduklarını göstermektedir. Öğretim elemanlarının ayrıca duygusal olarak etkilenmelerinden kaynaklı olarak hırslandıkları ve buna bağlı olarak daha fazla çalışmaya başladıkları da belirlenmiştir.

"Bu davranışı yapanları gördüğünde yolunu değiştirme, kendi işlerime yoğunlaşma (ancak durum ciddileştikçe kendi işlerimi de yapamaz olmuştum), diğer araştırma görevlisi arkadaşlarla dertleşme, bir nevi rahatlama seansı, çünkü neredeyse herkesin yaşadığı benzer şeyler vardı, yapılan ayrımcılığı dekana ve rektöre söyleme. Ama maalesef hiç bir yönetici öğretim üyesi varken araştırma görevlisine prim vermiyor. Şimdi tekrar yaşasam hemen bu insanlardan uzaklaşırdım, çünkü deneyimlerime göre böyle gelmiş böyle giden bir düşünce yapıları var, siz ne yapsanız fikirleri değişmiyor, dün bana idi bugün başka bir araştırma görevlisi arkadaşıma." (Araştırma Görevlisi, 33, Kadın)

"Bir an önce bir üst unvana geçebilmek için akademik çalışmalarıma hız katıyorum. Ayrıca ayrımcı davranışı sergileyenlerle mümkün olduğunca az görüşmeye çalışıyorum." (Yrd. Doç. Dr., 34, Kadın)

"Bu işi yapanları yok hükmünde sayıyorum." (Yrd. Doç. Dr., 53, Erkek)

"Bunu yapanlarla fazla iletişim kurmamaya ve yan yana gelmemeye gayret gösterdim. Arkadaşlarla bu durumu paylaştım çoğunlukla. Ama bunların pek bir etkisi olmadı." (Öğretim Görevlisi, 42, Kadın)

Tablo 9. Unvan ayrımcılığını ortadan kaldırmak için öğretim elemanlarının çözüm öneri

\begin{tabular}{llc}
\hline Temalar & Kodlar & F \\
\hline Demokrasi & $\begin{array}{l}\text { Üniversitelerin demokratik bir yapıya kavuşturulması ve } \\
\text { demokrasi bilincinin geliştirilmesi }\end{array}$ & 5 \\
\hline Liyakat & Akademisyen seçimlerinde bilimsel ve ahlaki ölçütlerin & 5
\end{tabular}


dikkate alınması

\begin{tabular}{llc}
\hline Yasal düzenleme & $\begin{array}{l}\text { Öğretim görevlilerine doktora yapma olanağının } \\
\text { sağlanması }\end{array}$ \\
& YÖK kanunun ayrımcılığı önleyecek şekilde değiştirilmesi & 2
\end{tabular}

Öğretim elemanları üniversitelerde yaşanan unvan ayrımcılığının önlenebilmesi için çeşitli çözüm önerileri sunmuşlardır. Bu çözüm yollarını demokrasi, liyakat ve yasal düzenlemeler oluşturmaktadır. Belirtilen bu üç çözüm önerisi de aynı sayıda belirtilmiştir. Üniversitelerin demokratik bir yapıya kavuşabilmesinde demokrasi bilincinin geliştirilmesi gerektiği belirtilirken liyakat için, akademisyen seçimlerinde bilimsel ve ahlaki ölçütlerin dikkate alınması önerilmiştir.

"Çalışma ortamındaki hiyerarşik yapıya sorgusuz sualsiz itaat ediyorlar. Mesela bir dekanı asla eleştiremiyorsunuz. Bölüm başkanı veya dekanı özgürce eleştirmek mümkün değil. Eleştirilerimizi demokratik bir tutumla dinleyip, kendilerini geliştirmeleri gerekir." (Araştırma Görevlisi, 30, Kadın)

Bunların yanında yasal düzenlemeler teması altında öğretim elemanları, öğretim görevlilerine doktora yapma olanağının sağlanması ve YÖK kanununun ayrımcılığı önleyecek şekilde değiştirilmesi önerilerini belirtmişlerdir.

"YÖK Kanununda değişiklikler yapılmalı öğretim üyelerinin kaderleri rektör, dekan veya idarecilerin inisiyatifinde olmamalı." (Yrd. Doç. Dr., 40, Kadın)

\section{SONUÇ, TARTIŞMA ve ÖNERILER}

Bu araştırmada, üniversitelerde yaşanan unvan ayrımcılığı ve ayrımcılığın etkilerinin belirlenmesi amaçlanmıştır. Araştırma sonucunda Yrd. Doç. Dr. ve öğretim görevlisi olarak çalışan öğretim elemanlarının çoğunlukla ayrımcı davranış olarak aşağılanma ve ders dağılımlarında adaletsizliğe maruz kaldıkları sonucuna ulaşılmıştır. Artut (2008) tarafından öğretim görevlilerinin sorunlarının belirlendiği araştırmada öğretim görevlilerinin fikirlerinin dikkate alınmadığı, öğretim üyeleri ve öğrenciler tarafından statülerinin sorgulandığı saptanmıştır ve araştırmanın sonucunu desteklemektedir. Araştırma görevlilerine uygulanan ayrımcı davranışların ise aşağılama, muhatap almama ve görev tanımı dışında işlerin yaptırılması olduğu belirlenmiştir. Bayar ve Bayar (2004) araştırma görevlileri ile ilgili metaforik algı çalışması sonucunda araştırma görevlilerinin görev tanımlarının açık olmaması nedeniyle kendileri ile ilgili olumsuz metaforlar ürettikleri sonucuna ulaşmışlardır. Benzer şekilde Korkut ve diğerleri (1999) tarafından araştırma görevlilerinin sorunlarının belirlendiği bir araştırmada da görev tanımlarının açık olmaması nedeniyle araştırma görevlilerinin sorun yaşadıkları belirlenmiştir ve araştırmanın bulgusunu destekler niteliktedir. Alanda daha önce yapılmış araştırmalarda belirlenen sorunlara benzer sorunların hala dile getiriliyor olması düşündürücüdür ve sorunların geçen zamanda çözülmemiş olduğunun bir göstergesi olarak değerlendirilebilir. Üniversitelerde unvan ayrımcılı̆ının yaşandığı belli bir zamanın veya dönemin olmadığı, herhangi bir zamanda yaşanabildiği belirlenmiştir. Ayrımcı davranışların çoğunlukla yönetim görevinde olan ve Prof. Dr. ve Doç. Dr. unvanına sahip akademisyenler tarafından yapıldığı belirlenmiştir. Unvan ayrımcılığının nedenleri arasında yüksek ego ve daha önce benzer şekilde ayrımcı davranışa maruz kalma belirtilmiştir. Akademik yaşamlarında 
benzer şekilde ayrımcılığa maruz kalan kişilerin daha sonra kendilerinin aynı davranışları sergilemeleri, bu durumun bir örgüt kültürüne dönüştüğü şeklinde yorumlanabilir ve fakülteler açısından bu durum oldukça sakıncalıdır. Aynı zamanda istenmeyen örgüt iklimi bu tür olumsuz çalışan davranışlarının öncülü olabilir. Doğan (2013) tarafından yeni kurulan üniversitelerde yaşanan sorunların belirlendiği bir araştırmada öğretim elemanlarının büyük çoğunluğu öğretim elemanları arasında mesleki işbirliği ve dayanışmanın azaldığını belirtmişlerdir. Benzer şekilde Argon ve Kösterelioğlu (2009) da akademisyenlerin akademik iletişim düzeylerini belirlemek için yaptıkları araştırmada akademisyenler arasında bilimsel bilginin yetersiz paylaşıldığı sonucuna ulaşmışlar ve bu algının unvana göre farklılaştığını belirlemişlerdir. Bu bulgular unvan ayrımcılı̆ını açıklayabilecek bir durumdur. İş birliğinin azalması, rekabetin artmasına ve bu da ayrımcılığa neden olabilmektedir.

Unvan ayrımcılığının mağdurlar üzerinde örgütsel ve bireysel etkilerinin olduğu sonucuna ulaşılmıştır. Ayrımcılığın örgütsel etkileri arasında kurum bağlıı̆̆ının ve iş yapma isteğinin azalması en fazla belirlenen etki olarak bulunmuştur. Ayrımcılığın bireysel olarak ise mutsuzluk ve gelecek kaygısı yarattığı belirlenmiştir. Unvan ayrımcılığı karşısında öğretim elemanlarının iletişim kurmama, susma ve yapılanları görmezden gelme davranışlarını çoğunlukla tercih ettikleri bulunmuştur. Bunların yanında bazı öğretim elemanlarının hırslanarak daha çok çalıştıkları da belirlenmiştir. İlk bakışta olumlu bir etki olarak yorumlanabilecek bu tepkinin kişiyi psikolojik olarak olumsuz etkileme olasılığı yüksektir. Aşırı hırs ve başarma isteği bireylerde iş stresine neden olabileceği gibi akademisyenlik gibi bir meslek göz önünde bulundurulduğunda etik ihlale (Aydın, 2006) neden olma olasılığı da vardır. Unvan ayrımcılığının önüne geçmek için öğretim elemanları, demokrasi ve liyakatın işe koşulması gerektiğini belirtmişler ve bunun denetimi ile yasal düzenlemelerini YÖK'ten beklediklerini ifade etmişlerdir.

Araştırmadan elde edilen sonuçlara göre aşağıdaki öneriler getirilmiştir:

- Fakülte yönetimlerinin demokratikleşmesi ve akademik statüye bakılmaksızın katılımcı bir yönetim anlayışının geliştirilmesi insan onuruna yakışır bir çalışma ortamının sağlanması açısından elzem görünmektedir. Bu nedenle üniversite ve fakülte yönetimlerinin demokratik, katılımcı ve eşitlikçi bir anlayışa geçebilmesi adına YÖK tarafından gerekli yasal düzenlemeler yapılabilir.

- Araştırma görevlilerinin görev tanımlarının açık bir şekilde yapılması özellikle iş yüklerinin sağlıklı bir şekilde planlanması açısından gereklidir.

- Ders dağılımları planlanırken uzmanlık alanları göz önünde bulundurulmalıdır.

- Bir kurumun niteliği o kurumdaki yöneticilerin yönetsel etkinliklerinin niteliğinden bağımsız düşünülemez. Fakültelerde bölümlerin uygulamalarının adalet ve etik açıdan fakülte yönetimi tarafından denetlenmesi adil olmayan uygulamaların önüne geçebilir.

- Araştırma görevlilerinin iş yüklerinin azaltılması için fakültelerde memurların görev tanımları çeşitlendirilebilir.

- Üniversite ve fakülte yönetimleri daha olumlu bir örgüt iklimi yaratmak adına farklı kültürel ve sanatsal etkinliklerle öğretim elemanları arasından daha sağlıklı ilişkiler oluşmasına katkı sağlayabilirler.

- Bu araştırmada unvan ayrımcılığı, etkileri ve nedenleri incelenmiştir. Unvan ayrımcılığının önüne geçebilmek adına öncüllerinin belirlendiği araştırmalara da ihtiyaç vardır. Araştırmacılar 
tarafından unvan ayrımcılığına neden olan bireysel ve örgütsel değişkenleri belirlemek amacıyla araştırmalar yapılabilir.

\section{KAYNAKÇA}

Arap, S. (2010). Türkiye yeni üniversitelerine kavuşurken: Türkiye'de yeni üniversiteler ve kuruluş gerekçeleri. Ankara Üniversitesi SBF Dergisi, 65(1), 1-29.

Argon, T. ve Kösterelioğlu, M. (2009). Akademisyenlerin akademik iletişim düzeylerinin çeşitli değişkenler açısından incelenmesi. $1^{\text {st }}$ International Congress of Educational Research. Canakkale, Turkiye. Web: http://www.eab.org.tr/eab/2009/pdf/108.pdf

Arı, A. (2007). Üniversite öğretim elemanlarının sorunları. Manas Sosyal Bilimler Dergisi, 9 (17): 65-74.

Artut, K. (2008). Üniversitelerde öğretim görevlilerin sorunları ve çözüm önerileri. Eğitim Bilim Toplum, 6(23):50-69.

Ayan, S. ve Şahbudak, E. (2012). Üniversitelerde asistanlara yönelik psikolojik taciz: Gazi, Kocaeli ve Cumhuriyet Üniversitesi örneği. Sosyal ve Beşeri Bilimler Dergisi, 4(1): 297310.

Aydemir, M. ve Erşan, C. (2011). Yeni kurulan üniversitelerde örgütsel bağlılık sorunu. Afyon Kocatepe Üniversitesi, i.i.B.F. Dergisi, 13(1): 55-72.

Aydın, ì. (2006). Sosyal bilimlerde araştırmadan yayına etik değerler. Sosyal Bilimlerde Süreli Yayıncılık, I. Ulusal Kurultay Bildirileri.

Bayar, S. A. ve Bayar, V. (2004). Akademisyen ve öğrencilerin araştırma görevliliğine ilişkin metaforik algıları. Eğitimde Politika Analizi, 1(1), 26-48.

Bilge, F., Akman, Y. ve Kelecioğlu, H. (2007). Öğretim elemanlarının iş doyumlarının incelenmesi. Hacettepe Üniversitesi Eğitim Fakültesi Dergisi, 32: 32-41.

Çavuş, M. F., Gök, T. ve Kurtay, F. (2007). Tükenmişlik: Meslek Yüksekokulu Akademik Personeli Üzerine Bir Araştirma. ÇÜ Sosyal Bilimler Enstitüsü Dergisi, 16(2), 97-108.

Celep, C. ve Konaklı, T. (2013). Öğretim elemanlarının yıldırma yaşantıları: Nedenleri, sonuçları ve çözüm önerileri. Kuram ve Uygulamada Eğitim Bilimleri,13(1), 175-199.

Çınar, í. (2008). Üniversite ve bazı sorunları. Eğitişim Dergisi, 18. Web: http://www.efkandurmus.com/site/arsiv/52-18/307-ikram-universite.html

Çöl, G. ve Gül, H. (2005). Kişisel özelliklerin örgütsel bağlılık üzerine etkileri ve kamu üniversitelerinde bir uygulama. Atatürk Üniversitesi iktisadi ve Idari Bilimler Dergisi, 19(1): 291-306.

Doğan, D. (2013). Yeni kurulan üniversitelerin sorunları ve çözüm önerileri. Yükseköğretim ve Bilim Dergisi/Journal of Higher Education and Science, 3(2): 108-116.

Dost, M, ve Cenkseven, F. (2007). Devlet ve vakıf üniversitelerinde çalışan öğretim elemanlarının mesleki sorunları. Çukurova Üniversitesi Sosyal Bilimler Enstitüsü Dergisi, 16(2): 203-218.

Ergöl, Ş. Koç, G., Eroğlu, K., ve Taşkın, L. (2012). Türkiye'de kadın araştırma görevlilerinin ev ve iş yaşamlarında karşılaştıkları güçlükler. Yükseköğretim ve Bilim Dergisi, 2(1), 43-49. 
Eroğlu, E. (2004). Yükseköğretimde hizmet kalitesi. Ankara: Nobel Yayınevi.

Gündüz, M. (2013). Akademiyi anımsamak: anılarda üniversite sorunları ve eleştiriler. Journal of Higher Education \& Science/Yüksekögretim ve Bilim Dergisi, 3(1): 16-26

Karakütük, K. ve Özdemir, Y. (2011). Bilim insanı yetiştirme projesi (BiYEP) ve öğretim üyesi yetiştirme programının (ÖYP) değerlendirilmesi. Eğitim ve Bilim, 36(161), 26-38.

Korkut, H. (2001). Sorgulanan Yüksek Öğretim. Ankara: Nobel Yayınları.

Korkut, H., Mustan, T. ve Yalçınkaya, M. (1999). Araştırma görevlilerinin sorunları. Kuram ve Uygulamada Egitim Yönetimi Dergisi, 5(1), 19-36.

Marsh, H. W. \& Hattie, J. (2002). The relation between research productivity and teaching effectiveness: Complementary, antagonistic, or independent constructs? The Journal of Higher Education, 73(5), 603-641.

Mengi, F. ve SchregImann, S. (2013). Akademisyenlik bağlamında bilimsel üretkenliği etkileyen çevresel faktörler, Amasya Üniversitesi Eğitim Fakültesi Dergisi, 2(1): 1-17.

Mete, Y., A. (2013). Yüksek öğretim kurumlarında psikolojik yıldırma (terör) : uygulayanlar, mağdurlar ve seyirciler. JASSS Studies, 6 (2): 977-993.

Naktiyok, A. ve Karabey, C. N. (2005). İşkoliklik ve tükenmişlik sendromu. Atatürk Üniversitesi iktisadi ve Idari Bilimler Dergisi, 19(2): 179-198.

Paksoy, H. M. (2007). Üniversitelerde akademik personelin iş memnuniyeti: Harran üniversitesi örneği. Karamanoğlu Mehmetbey Üniversitesi Sosyal Ve Ekonomik Araştırmalar Dergisi,12(9): 138-151.

Richards, L. \& Morse, J. M. (2012). Readme first for a user's guide to qualitative methods. Sage.

Saylı, H. ve Uğurlu, Ö. Y. (2007). Kurumsal itibar ve yönetsel etik ilişkisinin analizine yönelik bir değerlendirme. Süleyman Demirel Üniversitesi iktisadi ve Idari Bilimler Fakültesi Dergisi, 12(3): 75-96.

Şentürk, i. (2012). Üniversitede Kadın Olmak: Akademik Örgütte Toplumsal Cinsiyet Sorunu: Nitel Bir Çalışma. Kadin/Woman 2000, 13(2): 13-46.

Tuzgöl-Dost, M. ve Cenkseven, F. (2007). Devlet ve vakıf üniversitelerinde çalışan öğretim elemanlarının mesleki sorunları. Çukurova Üniversitesi Sosyal Bilimler Enstitüsü Dergisi, 16(2):203-218.

Türk Sanayicileri ve İ̧̧ Adamları Derneği (TÜSIAD) (2008). Türkiye'de Yükseköğretim: Eğilimler, Sorunlar ve Firsatlar. Web: (http://www.tusiad.org.tr/FileArchive/EUA 08.pdf)

Yaman, E. ve Ruçlar, K. (2014). Örgüt kültürünün yordayıcısı olarak üniversitelerde örgütsel sessizlik. Yüksekögrretim ve Bilim Dergisi, 1(4), 36-50.

Yeşil, Y. ve Fidan, F. (2015). Kadın akademisyenlerin çalışma yaşam kalitesinin incelenmesi: devlet ve vakıf üniversitelerinde akademisyenler üzerine bir araştırma. Akademik Sosyal Araştırmalar Dergisi, 3(14): 238-248.

Yıldırım, A. ve Şimşek, H. (2008). Nitel Araştırma Yöntemleri. Ankara: Seçkin Yayıncılık

Yılmaz, E. ve Özdemir, G. (2012). Türkiye'de kadın akademisyen ve araştırmacıların karşılaştıkları sorunlar ve tarıma bakış açıları. Journal of Tekirdag Agricultural Faculty, 9(2): 50-56. 


\section{SUMMARY}

The title discrimination is to treat people unfairly because of the title they have. Title based discrimination is likely to be experienced in organizations such as universities, where employees can get different titles through promotion and exams. The seeds of title based discrimination is to hope to have the rights within the organization by keeping one title superior to another title. The main activities of academicians are teaching, research and public service. Their unhappiness is one of the important variables that affect the quality of these basic activities. One of the conditions for increasing quality in higher education is that the positive working environment of academicians. However, it is difficult to talk about the happiness and efficient work of the employees in the environments where negative organizational behaviors such as discrimination are exhibited. For this reason, the aim of this research is to determine the title based discrimination in the universities, the effects of this discrimination and the solutions of the academicians against discrimination. The study employed a phenomenologic research design. The sample consist of 34 academicians who have experienced title based discrimination. A semistructured interview form, developed by the author, was used as data collection tool. As a result of the research it was found that academicians are exposed to different title-based discriminatory behaviors according to their duties and titles. It has been determined that academicians who work as assistant professors are mostly exposed to humiliation and unfair distribution of courses; lecturers are exposed to unfair course distribution and over-examination task; research assistants have been given jobs other than job descriptions, humiliation, obstruction of participation in the meetings, and over-examination tasks. It has been determined that title based discrimination behaviors are mostly displayed by managers, associate professors, professors and assistant professors. According to the academicians title based discriminations stems from high ego, being similarly discriminated before and competitive personality. It has been also determined that when academicians exposed to title based discrimination they became unhappy, their organizational commitment level and desire for work reduce. It has been found that academicians against discriminations have adopted solutions such as not communicating, silence and working harder to have higher status. According to the results the study recommends to end the title based discrimination that necessary regulations can be made by Council of Higher Education in order to enable universities and faculty managers to reach a democratic, participatory and egalitarian mentality. Clear definition of the job descriptions of research assistants is essential, especially in order to plan workloads in a healthy way. Job descriptions of officials can be varied in faculties to reduce the workload of research assistants. Specializations should be taken into consideration while course distributions are planned. Supervision of the practice of departments by faculty management in faculties may prevent unfair practices. University and faculty administrations can contribute to the creation of healthy relationship among the academicians with different cultural and artistic activities in order to create a more positive organizational climate. 